\title{
A POSTMORTEM STUDY ON MORPHOMETRY OF THE HUMAN STOMACH IN A BANGLADESHI POPULATION
}

\author{
BEGUM GN ${ }^{1}$, NURUNNABI ASM ${ }^{2}$, SHAHRIAH S ${ }^{3}$, RAYHAN KA ${ }^{4}$, PERVEN HA ${ }^{5}$
}

\begin{abstract}
:
Context: A Cross-sectional, descriptive type of study was done in the Department of Anatomy, Dhaka Medical College, Dhaka, from July 2005 to June 2006, to see the variation in the size of the stomach with age in Bangladeshi people.
\end{abstract}

\begin{abstract}
Methods: The study was performed on 60 post mortem human stomach collected from unclaimed dead bodies which were in the morgue under examination in the Department of Forensic Medicine, Dhaka Medical College, Dhaka. The samples were divided into four age-groups including group A (2-16 years), group B (17-22 years) and group C (23-65 years). The length and breadth of each stomach were measured by using a measuring tape.
\end{abstract}

Results: The mean length of the stomach were found $12.18 \pm 1.77 \mathrm{~cm}$ in group A, $17.74 \pm 1.95$ $\mathrm{cm}$ in group $B$, and $25.31 \pm 1.63 \mathrm{~cm}$ in group $C$. The mean breadth of the stomach were found $6.81 \pm 0.40 \mathrm{~cm}, 8.26 \pm 0.57 \mathrm{~cm}$ and $9.54 \pm 0.45 \mathrm{~cm}$ in group $A, B$ and $C$ respectively. The differences between age groups were statistically significant $(P<0.001)$.

Conclusion: The length and breadth of the human stomach increase with age.

Key words: Stomach, morphometry, length, breadth.

J Dhaka Med Coll. 2013; 22(1) : 16-18.

\section{Introduction:}

The stomach is the most dilated part of the alimentary canal ${ }^{1}$. It acts a reservoir of food and helps in digestion partly ${ }^{2}$. The size and shape of the stomach vary greatly from person to person, depending on age, body habitus, posture, and interval since eating ${ }^{3,4}$. Several studies have been done on different population to determine the size of the normal stomach ${ }^{5-}$ 7. People residing in the Indian subcontinent tends to have a small stomach, where underlying cause is still unknown. The probable explanation may be difference in nutritional status, dietary habits or ethnic differences ${ }^{7}$. It has been observed by various researchers that the dimensions of different organs in Bangladeshi population have got variations from those of the western population $^{8}$. It is also observed by reviewing the literatures and the texts that only few works have been done on the morphological aspects of the stomach in foreign countries, and sufficient attention has not been given in such morphological experiment in our country as well ${ }^{9}$. To the best of our knowledge, there is only one existing record regarding the dimension of stomach in Bangladeshi population ${ }^{9}$. Therefore, it has been designed to see the length and breadth of this important organ in different age groups in a Bangladeshi population following autopsy.

\section{Methods:}

A cross-sectional descriptive study was carried out in the Department of Anatomy, Dhaka Medical College, Dhaka, from July 2005 to June 2006, based on the postmortem collection of human stomach. 60 human stomach were

1. Dr. Gul Newaz Begum, Associate Professor, Department of Anatomy, Anwer Khan Modern Medical College, Dhaka.

2. Dr. Abu Sadat Mohammad Nurunnabi, Lecturer, Department of Anatomy, Dhaka Medical College, Dhaka.

3. Dr. Sunjida Shahriah, Associate Professor, Department of Anatomy, Z.H. Sikder Women's Medical College, Dhaka.

4. Dr. Khandaker Abu Rayhan, Associate Professor, Department of Anatomy, Popular Medical College, Dhaka.

5. Dr. Hosna Ara Perven, Assistant Professor, The Medical College for Women \& Hospital, Uttara, Dhaka.

Correspondence: Dr. Gul Newaz Begum, Associate Professor, Department of Anatomy, Anwer Khan Modern Medical College, Dhaka. Email: gulnewaz@yahoo.com 
collected from the unclaimed dead bodies that were under examination in the Department of Forensic Medicine of Dhaka Medical College, Dhaka. All the samples were collected within 24-36 hours of death without any sign of putrefaction and taken from medicolegal cases excluding poisoning, any cutting or crushing injury to stomach, and grossly abnormal viscera. During collection appropriate age, sex and cause of death were noted from morgue's record book. The samples were tagged immediately, which was bearing a code number for subsequent identification. Soon after collection, each sample was gently washed in tap water on a dissection tray. Blood and blood clots were removed as far as possible. Omenta, fat and other unwanted tissues were also removed. Then the samples were fixed in $10 \%$ formol saline solution. After isolation, the samples were divided into three age-groups, i.e. group A (2-16 years), group B (17-22 years), and group C (23-65 years), according to Farinati et al. (1993) ${ }^{10}$ (Table-I). Then the length and breadth of each stomach were measured by using a measuring tape. The present study was approved by the Ethical Review Committee of Dhaka Medical College, Dhaka.

\section{Table-I}

Grouping of the sample of the present study $(n=$ 60)

\begin{tabular}{lcc}
\hline Group & $\begin{array}{c}\text { Age limit } \\
\text { in years }\end{array}$ & $\begin{array}{c}\text { Number of } \\
\text { samples }\end{array}$ \\
\hline A & $2-16$ & 11 \\
B & $17-22$ & 12 \\
C & $23-65$ & 37 \\
\hline
\end{tabular}

\section{Results:}

The mean length of the stomach were found $12.18 \pm 1.77 \mathrm{~cm}$ in group A, $17.74 \pm 1.95 \mathrm{~cm}$ in group $\mathrm{B}$, and $25.31 \pm 1.63 \mathrm{~cm}$ in group $\mathrm{C}$. The mean breadth of the stomach were found $6.81 \pm 0.40 \mathrm{~cm}, 8.26 \pm 0.57 \mathrm{~cm}$ and $9.54 \pm 0.45 \mathrm{~cm}$ in group $\mathrm{A}, \mathrm{B}$ and $\mathrm{C}$ respectively. The differences between age groups were statistically significant $(\mathrm{P}<0.001)$ (Table-II).
Table-II

Length and breadth of stomach in different study groups

\begin{tabular}{lcc}
\hline $\begin{array}{l}\text { Group } \\
(\mathrm{n})\end{array}$ & $\begin{array}{c}\text { Length (in cm) } \\
\text { Mean } \pm \text { SD }\end{array}$ & $\begin{array}{c}\text { Breadth (in cm) } \\
\text { Mean } \pm \text { SD }\end{array}$ \\
\hline $\mathrm{A}$ & $12.18 \pm 1.77$ & $6.81 \pm 0.40$ \\
$(11)$ & $(9.52-14.32)$ & $(6.20-7.35)$ \\
$\mathrm{B}$ & $17.74 \pm 1.95$ & $8.26 \pm 0.57$ \\
$(12)$ & $(15.50-20.43)$ & $(7.22-9.22)$ \\
$\mathrm{C}$ & $25.31 \pm 1.63$ & $9.54 \pm 0.45$ \\
$(37)$ & $(21.52-28.35)$ & $(8.83-10.50)$ \\
\hline & $\mathrm{P}$ value & $\mathrm{P}$ value \\
\hline A vs B & $<0.001^{* * *}$ & $<0.001^{* * *}$ \\
A vs C & $<0.001^{* * *}$ & $<0.001^{* * *}$ \\
$\mathrm{~B}$ vs C & $<0.001^{* * *}$ & $<0.001^{* * *}$ \\
\hline
\end{tabular}

Figures in parentheses indicate range. Statistical analyses were done by ANOVA (multiple comparison), ${ }^{* * *}=$ significant.

\section{Discussion:}

Osemlak et al. (1982) ${ }^{11}$ studied on 51 stomachs taken from dead bodies of newly born children. The length of the empty stomachs ranged from 32-85 $\mathrm{mm}$ (mean $53.6 \mathrm{~mm}$ ) in premature newborns, where as 48-97 mm (mean $72.9 \mathrm{~mm}$ ) in full term newborns. The stomachs of male were found broader than that of female newborns. Rahman $(1993)^{9}$ found that the average length of the stomach ranges from 5$25 \mathrm{~cm}$. and breadth from $3-10 \mathrm{~cm}$. with varying age. Garg (2004) ${ }^{12}$ stated that the average length of the stomach is about $25 \mathrm{~cm}$ in adult. Only few data were found to compare with our study. However, the findings of our present study are more or less similar to those previous findings.

\section{Conclusion:}

The present study showed that the length and breadth of the human stomach increase with age. The results of the present study can be used as a standard reference for the stomach of Bangladeshi people. However, further studies with larger sample and comparison between sexes are recommended. 


\section{References:}

1. Borley NR. Abdominal oesophagus and stomach. In: Standring S, Borley NR, Collins P, Crossman AR, Gatzoulis MA, Healy JC, et al. eds. Gray's anatomy: the anatomical basis of clinical practice. $40^{\text {th }}$ ed. London: Elsevier Churchill Livingstone; 2008: p. 1111 .

2. Raufman JP, Goldberg E. Stomach and duodenum: anatomy and structural anomalies. In: Yamada T, Alpers DH, Kalloo AN, Kaplowitz N, Owyang C, Powell DW. eds. Textbook of gastroenterology. $5^{\text {th }}$ ed. Vol.1. Oxford: Blackwell; 2009: p.889-902.

3. Newton JL. Effect of age-related changes in gastric physiology on tolerability of medications for older people. Drugs Aging 2005; 22(8): 655-61.

4. Valle JD, Todisco A. Gastric secretion. In: Yamada T, Alpers DH, Kalloo AN, Kaplowitz N, Owyang C, Powell DW. eds. Textbook of gastroenterology. $5^{\text {th }}$ ed. Vol.1. Oxford: Blackwell; 2009: p.284-329.

5. Goldsmith HS, Akiyama H. A comparative study of Japanese and American gastric dimensions. Ann Surg 1979; 190(6): 690-3.

6. Cox AJ. Stomach size and its relation to chronic peptic ulcer. Arch Path 1952; 54: 407-22.
7. Naik SR, Bajaj SC, Goyal RK, Gupta DN, Chuttani HK. Parietal cell mass in healthy human stomach. Gastroenterology 1971; 61(5): 682-5.

8. Enayetullah M. Gross and histomorphological study of the thyroid and parathyroid glands in Bangladeshi people. [Thesis]. Dhaka: IPGMR, University of Dhaka; 1996.

9. Rahman MM. An anatomical study of age and sex related changes in human postmortem stomach of Bangladeshi people. [Thesis]. Dhaka: IPGMR, University of Dhaka; 1993.

10. Farinati F, Formentini S, Della Libera G, Valiante F, Fanton MC, Di Mario F, et al. Changes in parietal and mucous cell mass in the gastric mucosa of normal subjects with age: a morphometric study. Gerontology 1993; 39(3): 146-51.

11. Osemlak J, Siwek R, Chomiak A. Dimensions and shape of the stomach in newborns. Folia Morphol 1982; 41(3): 295-306.

12. Garg K. ed. BD Chaurasia's Human anatomy: regional and applied. $4^{\text {th }}$ ed. Vol.2. New Delhi: CBS Publishers \& Distributors; 2004: p.238. 